\title{
The Effect of Giving Religious Coping Handbook Therapy on Stress and Anxiety in Final Year Students of the Bachelor of Nursing Study Program at Muhammadiyah University of Purwokerto
}

Uci Yuning Prapti ${ }^{1}$, Siti Nurjanah ${ }^{2}$

${ }^{1,2}$ Department of Health, Universitas Muhammadiyah Purwokerto, Indonesia

\begin{tabular}{l}
\hline ARTICLE INFO \\
\hline Article history: \\
DOI: \\
10.30595/pshms.v2i.236 \\
Submitted: \\
December 6, 2021 \\
Accepted: \\
January 21, 2022 \\
Published: \\
January 26, 2022 \\
Keywords: Anxiety; \\
Stress; Roping \\
Religious $\quad$ Handbook; Students
\end{tabular}

\begin{abstract}
Obstacles in writing a thesis can make students experience stress, anxiety, low selfesteem, frustration, loss of motivation, and delaying writing a thesis and some even decide not to finish their thesis. Coping mechanism is a way of dealing with stress and anxiety by deceiving oneself. Religious coping is one way to deal with stress with a religious approach. The aim of this research is to determine the effect of giving religious coping handbook therapy on stress and anxiety in final year students of the Bachelor of Nursing Study Program at Muhammadiyah University of Purwokerto. This study is a pre-experimental study with a one group pretest-posttest design. Purposive sampling technique with a total of 23 respondents according to the inclusion and exclusion criteria. The research instrument used the DASS and IROPE questionnaire. Data analysis using Wilcoxon test. The results showed that the stress of students before being given therapy had an average score of 35.57 and after therapy had an average score of 6.61. Anxiety of students before being given therapy has an average score of 31.91 and after being given therapy has an average score of 4.17. There is an effect of giving religious coping handbook therapy to stress and anxiety in final year students of the Bachelor of Nursing Study Program at Muhammadiyah University of Purwokerto ( $\mathrm{p}$ value: 0.0001 ). There was a decrease in stress and anxiety scores after being given religious coping handbook therapy.
\end{abstract}

This work is licensed under a Creative Commons Attribution 4.0 International License.

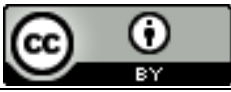

Corresponding Author:

Siti Nurjanah,

Department of Health, Universitas Muhammadiyah Purwokerto,

Soepardjo Rustam Street KM. 7, Banyumas, Indonesia

Email: sitinurjanah.ump@gmail.com

\section{INTRODUCTION}

Final year students are students who are in the process of working on their final project or thesis. The final project is one of the mandatory parts for students to complete academic education in the undergraduate program in the form of scientific work (KBBI, 2014). Thesis is one of the standards for students to be declared as graduating from the academic process that has been determined (Sustra, 2011). Thesis aims to train students' skills in solving problems scientifically by conducting research, analyzing and drawing conclusions by reporting the results of the research in the form of a thesis (Rohmah, 2016).

The process of completing a thesis is not easy, writing a thesis for some students is considered a very difficult job (Rizkiyati, 2019). Difficulty in finding literature, limited funds, not accustomed to writing in the sense of writing scientific papers, less familiar with the scheduled work system with such tight timing and problems with supervisors are some of the problems faced by students during the thesis preparation process.[1] 
Obstacles in writing the thesis will eventually create stress, anxiety, low self-esteem, frustration, loss of motivation, and delaying the preparation of the thesis and some even decide not to complete the thesis.[2] The responsibilities and demands of academic life on students can be part of the stress experienced by students. Stress is a human psychological reaction or response when faced with things that are felt to have exceeded the limit or are considered difficult to deal with. Every human being has experience of stress even before humans are born.[3] Academic stress is mental and emotional pressure, or pressure that occurs due to the demands of campus life.[4]

Research conducted by Fatmawati \& Sari [5] in the undergraduate nursing study program in Surakarta, obtained data that $86.8 \%$ of students experienced moderate stress, $9.4 \%$ of students experienced mild stress and $3.8 \%$ of students experienced severe stress when facing their thesis. . Research conducted by Julianti [6] shows that $65 \%$ of final year undergraduate students in Nursing experience stress.

Stress that occurs in students can be caused by several factors such as personal factors, family factors and academic factors. Personal factors include not being able to divide time, family factors including family support and academic factors including too many tasks or piling tasks (Saam \& Sri, 2013). Research conducted by Khan [7] states that there is a relationship between family factors and stress in students. Rakhmawati [8] in her research stated that students who received social support from friends would experience lower stress levels than students who did not get support from friends.

Fawzy (2017) says that stress can cause anxiety, depression, poor sleep quality, poor academic performance, alcohol use and substance abuse, reduced satisfaction and quality of life, loss of self-confidence and the risk of psychiatric disorders or even suicidal ideation and attempts. Siswadi (2018) revealed that there were two final year students who decided to end their lives within one week. There is a phenomenon that specifically occurred in 2018, where a student with the initials RWP, who is a 13th semester student at Padjadjaran University, Faculty of Fisheries and Marine Affairs decided to end her life when completing her thesis. RWP was found dead by hanging himself, the incident was suspected to be due to an unfinished thesis.[9]

The results of the research by Oladipo and Ogungbamila [10] show that Feelings of wanting to cry, leaving the exam room, not taking the test/guidance, feeling angry or helpless and shaking hands are behavioral responses shown by students because they experience anxiety during the thesis preparation process. The results of Hidayati's research (2020) showed that $16.3 \%$ of nursing students experienced a high level of anxiety in doing thesis. Gunawan's research (2020) also shows that 55\% of students experience anxiety while working on their thesis.

The higher the level of stress and anxiety, the need for a coping mechanism that is used by individuals to overcome the problems that occur. Coping mechanism is a way of overcoming stress and anxiety by self-empowerment.[11] There are two types of coping strategies that students can use when facing problems, namely problem focused coping and emotion focused coping (Ramadhanti, 2019). Research conducted by Adiwaty (2015) shows that coping strategies have a positive influence on self-adjustment and are acceptable.

Mulyadi (2012) states that the environment influences the way a person determines coping strategies. Muhammadiyah University of Purwokerto is one of the universities that has an Islamic vision and mission to actualize Islamic principles and values in university administration. Based on the university environment, religion plays a role in student coping styles in addition to problem focused coping and emotion focused coping. This is because religion as a life guide can be used as a problem solving strategy by someone

Religion plays an important role in the lives of many individuals in adulthood and is related to their health and coping. Religious activities and belief in religion, were found to be effective in solving anxiety and depression disorders. So it can be said that religious coping is one strategy to solve problems through worship activities, improving relationships with God, and other spiritual activities (John, 2011). Pargament (1997) calls it the term religious coping. Religious coping is an effort to understand and deal with stress by using religious beliefs and religious practices to respond to what is being experienced (Pargament, Feuille \& Burdzy, 2011)

Religious coping is one way to deal with stress with a religious approach (Xu, 2015). Religious coping done in 3ways, namely: self-directing, defering, and collaborative. Self-directing strategies help individual actions in solving problems. Individuals who use this strategy see themselves as God-given abilities and resources to solve problems. Strategy defffering, shows if God arranges a strategy in solving individuals actually. Individuals depend on God to give signs or cues to tell individuals which problemsolving approach to use. Collaborative strategy is the most common coping strategy, in this case the individual and God do not play a passive role in the problem solving process, but both together solve individual problems (Alflakseir \& Coleman, 2011).

Implementation of religious coping can be done through a series of worship practices such as prayer, remembrance, prayer, and reading the Qur'an. The results of Iredho's research (2016) show that reading the 
Qur'an is a positive energy that can reduce the negative energy that has been taken in one's body, soul and mind. The implementation of religious coping can be carried out well when someone has a manual or handbook that aims to always remind or teach someone to do the implementation. Winchell (2013) states that a handbook is a book that contains information, a guide on a type of activity that is used for guidance in the application of practice.

The results of a preliminary study conducted on November 8, 2020 at the Faculty of Health, University of Muhammadiyah Purwokerto, obtained data on the number of undergraduate Nursing Study Program students taking theses in the 2020/2021 academic year as many as 235 students. The results of a preliminary study of 5 students by giving the DASS questionnaire showed that $60 \%$ of students had an average stress score of 32 and an average anxiety score of 28 . As many as $40 \%$ had an average stress score of 30 and an average anxiety score of 22 . These results indicate that most experience moderate stress and anxiety.

The results of the interview found that the cause of stress and anxiety was that 3 students experienced feelings of fear when they would contact the lecturer for fear of making a wrong word, while 2 students said they were afraid and anxious when they were going through the process of preparing for the proposal trial. Stress and anxiety experienced by students are also caused by difficulties in finding references, unfinished revisions and changing titles in the middle of the guidance process.

Based on the description of the background above, the researchers are interested in conducting research on "The Effect of Giving Religious Coping Handbooks on Stress and Anxiety in Final Year Students of the Bachelor of Nursing Study Program at Muhammadiyah University of Purwokerto."

\section{RESEARCH METHOD}

This study is a pre-experimental study with a one group pretest-posttest design. Purposive sampling technique with a total of 23 respondents according to the inclusion and exclusion criteria. The research instrument used the DASS and IROPE questionnaire. Data analysis using Wilcoxon test.

\section{RESULT AND DISCUSSIONS}

1. Description of respondent characteristics based on age, gender of final year undergraduate nursing students at Muhammadiyah University of Purwokerto. Table 4.1

\begin{tabular}{lll}
\hline Variable & Frequency (f) & Precentage (\%) \\
\hline 1. Age & 2 & \\
a. 20 years & 15 & 8.7 \\
b. 21 years & 5 & 65.2 \\
c. 22 years & 1 & 21.8 \\
d. 23 years & & 4.3 \\
2. Gender & 4 & \\
a. Male & 19 & 17.4 \\
b. Female & 23 & 82.6 \\
\hline Total & & 100 \\
\hline
\end{tabular}

Table 4.1 Shows that most of the respondents have the age of 21 years as many as 15 respondents $(65.2 \%)$, and most of the respondents are female as many as 19 respondents $(82.6 \%)$.

2. Overview of stress in final year students before being given religious coping handbook therapy for the Bachelor of Nursing Study Program at the University of Muhammadiyah Purwokerto. Table 4.2

\begin{tabular}{lllll}
\hline Variable & Mean & SD & Median & Min-Max \\
\hline Stress Before & 35.57 & 3.342 & 36 & $26-40$ \\
\hline
\end{tabular}

Table 4.2 Showed that the stress of students before being given religious coping handbook therapy had an average score of 35.57 (very severe/panic category) with the lowest score of 26 (severe category) and the highest score of 40 (very severe/panic category).

3. Overview of anxiety in final year students before being given religious coping handbook therapy for the Bachelor of Nursing Study Program at the University of Muhammadiyah Purwokerto. Table 4.3

\begin{tabular}{lllll}
\hline Variable & Mean & SD & Median & Min-Max \\
\hline Anxiety Before & 31.91 & 2.503 & 32 & $24-34$ \\
\hline
\end{tabular}


Table 4.3 Shows that students' anxiety before being given religious coping handbook therapy had an average score of 31.91 (very severe/panic category) with the lowest score of 24 (very severe category) and the highest score of 34 (very severe/panic category).

4. Overview of stress in final year students after being given religious coping handbook therapy for the Bachelor of Nursing Study Program at Muhammadiyah University of Purwokerto. Table 4.4

\begin{tabular}{lllll}
\hline Variable & Mean & SD & Median & Min-Max \\
\hline Stress Week II & 17.96 & 2.513 & 19 & $10-20$ \\
Stress Week IV & 6.61 & 2.126 & 7 & $2-12$ \\
\hline
\end{tabular}

Table 4.4 Showed that student stress after being given religious coping handbook therapy for 30 minutes x 14 days had an average score in the second week of 17.96 (mild category) with the lowest score of 10 (normal category) and the highest score of 20 (moderate category). After being given for 30 minutes x 28 days, the average score in week IV was 6.61 (normal category) with the lowest score of 2 (normal category) and the highest score of 12 (normal category).

5. Overview of anxiety in final year students after being given religious coping handbook therapy for the Bachelor of Nursing Study Program at the University of Muhammadiyah Purwokerto. Table 4.5

\begin{tabular}{lllll}
\hline Variable & Mean & SD & Median & Min-Max \\
\hline Anxiety Week II & 18.13 & 1.486 & 18 & $16-22$ \\
Anxiety Week IV & 4.17 & 1.992 & 4 & $1-8$ \\
\hline
\end{tabular}

Table 4.5 Showed that students' anxiety after being given religious coping handbook therapy for 30 minutes $\mathrm{x}$ 14 days had an average score in the second week of 18.13 (tagged category) with the lowest score of 16 (severe category) and the highest score of 22 (very severe category). After being given for 30 minutes x 28 days, the average score at week IV was 4.17 (normal category) with the lowest score of 1 (normal category) and the highest score of 8 (mild category).

6. The effect of giving religious coping handbook therapy to stress and anxiety in final year students of the Bachelor of Nursing Study Program at Muhammadiyah University of Purwokerto. Table. 4.6

\begin{tabular}{llll}
\hline Variable & Mean Rank & $\mathbf{Z}$ & $\boldsymbol{p}$-value \\
\hline Stress Before - After & -28.96 & -4.207 & 0.0001 \\
Anxiety Before - After & -27.74 & -4.207 & 0.0001 \\
\hline
\end{tabular}

Table 4.6 Showed that there was a decrease in stress scores after being given religious coping handbook therapy of 28.96 and there was an effect of giving religious coping handbook therapy on stress in final year students of the Bachelor of Nursing Study Program at Muhammadiyah University of Purwokerto with a pvalue of $0.0001(<0.05)$. The results also found that there was a decrease in anxiety scores after being given religious coping handbook therapy of 27.74 and there was an effect of giving religious coping handbook therapy on anxiety in final year students of the Bachelor of Nursing Study Program at Muhammadiyah University of Purwokerto with a p-value of $0.0001(<0.05)$.

\section{CONCLUSION}

Based on the results and discussions that have been carried out, it can be said that there is an effect of giving religious therapy on stress and final year students of the Nursing Study Program at Muhammadiyah University of Purwokerto with a p-value of $0.0001(<0.05)$.

\section{Acknowledgements}

Thank you to Allah SWT, both parents and all comrades in arms who have helped from beginning to end.

\section{REFERENCES}

[1] Abiyoga, "Faktor-faktor Yang Berhubungan Dengan Kejadian Gout Pada Lansia Di Wilayah Kerja Puskesmas Situraja Tahun 2014," Jurnal Darul Azhar, vol. 2, no. 1, p. 47-56, 2017.

[2] M. Katuuk, "Hubungan Kemunduran Fisiologis Dengan Tingkat Stres Pada Lanjut Usia Di Puskesmas Kakaskasen Kecamatan Tomohon Utara," Jurnal Keperawatan, vol. 6, no. 1, 2018.

[3] Risdianto, "Hubungan Dukungan Sosial dengan Kualitas Hidup Lanjut Usia di Desa Kembang Kuning 
Cepogo Boyolali.," Skripsi Fakultas Ilmu Kesehatan Universitas Muhammadiyah Surakarta, tidak dipublikasikan, Surakarta, 2009.

[4] Nugroho, Keperawatan Gerontik \& Geriatrik, 3 ed., Jakarta: EGC, 2008.

[5] Rohaedi, Putri , Karimah , "Tingkat Kemandirian Lansia Dalam Activities Daily," Pendidikan Keperawatan Indonesia, vol. 2, no. 1, p. 17, 2016.

[6] Priyoto, Teori Sikap \& Perilaku dalam Kesehatan, Yogyakarta: Nuha Medika, 2014.

[7] T. Y, "General Self Efficacy in Elderly Living in Rest Homes. Tehran. Iran," Journal of Nursing.

[8] M. Heidari and M. ghodusi, "Comparative Self Efficacy in Elderly and Non Elderly ResidentsOf Family and Nursing Home in Shahrekord. Shahrekord.," Quarterly Journal of Geriatric Nursing, 2015.

[9] E. Irawan and F. Amelia, "Hubungan Self Efficacy Dengan Perawatan Diri Lansia Hipertensi," vol. 2, p. 130-139, 2017.

[10] Nursalam, Metedologi penelitian ilmu keperawatan, 4 ed., Jakarta: Salemba Medika, 2015.

[11] A. Dwi, Arifianto and Auliazardh, "Faktor faktor yang berhubungan dengan kemandirian activity of daily living ADL pada pasien post stroke di rehabilitasi medik RSUD Tuggurejo Semarang," Jurnal NERS Widya Husada, vol. 3, no. 1, 2016.

[12] Purwanto, Psikologi Pendidikan, Bandung: PT Remaja Rosdakarya, 2017.

[13] Gufron, Teori-Teori Psikologi, Ar-Ruzz Media, 2010.

[14] K. Putri, "Pengaruh Motivasi , Aktifitas dan Pemenuhan Tugas Pengembangan Terhadap Kepuasan Hidup Lansia Duda dan Janda," IPB, BOGOR, 2015.

[15] V. Paskalini, "Hubungan Dukungan Sosial dan Motivasi Dengan Perawatan Mandiri Pada Pasien Diabetes Melitus Tipe 2 di Poliklinik Penyakit Penyakit dalam RSUD Nokopindo Toli Toli," vol. 5, no. $1,2017$.

[16] . J. G. Kim, K. H. Moon, E. S. Lim and J. H. Yoo, "[1 A Study on IADL, Stress and Motivation on Healthy Lifestyle among Elderly People with Arthritis.," Journal of the Korea Academia-Industrial Cooperation Society, vol. 17, no. 3, p. 209-217, 2016.

[17] D. Malida, "Faktor Yang Mempengaruhi Tingkat Kemandirian Lansia Dalam Melakukan Aktifitas Kehidupan Sehari - hari Di Panti Sosial Tresna Werdha Budi Luhur Kota Jambi," Jambi, 2011.

[18] J. Doumit and R. Nasser, "Quality of life and wellbeing of the elderly in Lebanese nursing homes.," International Journal of Health Care Quality Assurance, vol. 23, no. 1, p. 72-93, 2010. 